\title{
Parameters of cytokine regulation as additional criterion of immunodiagnosis
}

\author{
Z. R. Ter-Pogosyan
}

National Center of Oncology named after V. A. Fanarjyan, MH Republic of Armenia 76, Fanarjyan Str., Yerevan, Republic of Armenia, 0052

zarine@arminco.com

\begin{abstract}
Aim. The work goal was to search more informative parameters of cytokine system for laboratory diagnosis in oncological and non-oncological pathology. Methods. The concentrations of some cytokines and chemokines (IL-4, 6, 8 and ralL-1), interferones (IFN-alpha, gamma), (VEGF) have been investigated. Results. Outcoming levels of investigated cytokines have exceeded the norm mostly in patients with malignant tumor of brain. The serum level raIL-1 increased in patients with lung cancer and a decrease of this indicator was detected by the end of treatment. Concentration of IL-8 in blood serum, initially increased, in majority of them, $82 \%$, remained at the previous level by the end of investigation; the averaged level IL-6 was slightly increased and decreased by the end of investigation approximately reaching the norm limits. Serum level raIL-1 increased in $70 \%$ of patients with polytrauma and decreased by the end of treatment. Indicators IL-6 and IL-8 in the same patients initially increased and slightly decreased by the end of investigation. Concentration of VEGF in patients with high level malignancy (G3) comprised $285.9 \pm 27.2 \mathrm{pg} / \mathrm{ml}$ with a slight increase by the end of investigation while in low level malignancy a reliable decrease in its content was detected. The serum level VEGF in patients with polytrauma increased by the end of investigation, thus in majority of investigated patients with favorable illness process statistically sufficient decrease was detected. Conclusions. The results obtained will help to select much more informative biomarkers that have diagnostic and prognostic importance.
\end{abstract}

Keywords: cytokins, immunodiagnostics, tumors, polytrauma, sepsis.

Introduction. Taking into consideration that cytokines play a principal role in the regulation of immune response, yet the literature data about cytokine secretion in different pathologies are scanty and enough controversial, the understanding of cytokine synthesis mechanisms may provide possibilities for its selected correction [1]. However, the present literature information about antiinflammatory cytokines in oncological diseases is mostly controversial and interpreted in different ways by different authors [2-4]. It is known, that the tumor cells may be a production source of different cytokines which may be used to strengthen the own growth [5-7]. In the blood of patients with oncological diseases, the

(C) Institute of Molecular Biology and Genetics, NAS of Ukraine, 2011 production of various inhibitors, such as cytokines and their activity are coming into view $[7,8]$.

Presently, the diagnostic value of measurable concentration of IFN-alpha and gamma in blood is established. FNO-alpha and IL-1 have similar effects on cell function and usually are classified together with inflammatory cascade, as far as the initiating cytokines frequently are correlated with the indicators of severity of pathological process.

Definition of serum-born concentration of IL-1, 2, $4,6,8,10$, FNO-alpha presently is offered not only for «standard» immunologic examination but also for differentiation of septic complication phase [9-12]. As regards to IL-8, there are data on its important role in various infectious and traumatic processes [12-14]. Thus, 
as per data presented by Kozlov [15], especially the disbalance of cytokines but not the general level of hypercytokinemia is characteristic of pathogenesis of different pathology, such as functional condition of CD4 cells tested by cytokine profile - the functional activity of TH1 subpopulation is confirmed by IFN-gamma production, while the activity of TH2 subpopulation is confirmed by IL-4 [11] production. In this way, cytokines may become potentially new serum-born markers for pathology with poor prognosis.

Therefore, the work goal is to search more informative parameters of cytokine system for laboratory diagnosis in oncological and non-oncological pathology.

Material and methods. The concentration of some cytokines and chemokines (IL-4, 6, 8 and raIL-1), interferones I and II types ( IFN-alpha, gamma), angiogenesis factor (VEGF) involved in regulation of compensator immune response in 137 patients with malignant tumor in various localization (lung cancer, ovary cancer, urinary bladder cancer, brain tumors) as well as in 83 patients with polytrauma and septic complications have been investigated. The investigation of cytokine status has been conducted at the admission during 1-2 days and through a week after end of treatment.

To determine the capability on production of cytokines, the lymphocytes at concentration of $2 \mathrm{mln} / \mathrm{ml}$ separated from peripheral blood have been cultivated in medium RPMI- 1640 by $10 \%$ of embryonic fetal serum and phytohemagglutinin (PHA) at dose of $10 \mu \mathrm{g} / \mathrm{ml} \mathrm{du}-$ ring $72 \mathrm{~h}$. The obtained supernatants have been kept at $-20{ }^{\circ} \mathrm{C}$ before testing.

The concentrations of cytokines in blood serum and in cultivation liquid have been examined by ELISA «Diaclone» (France) and «Vector-Best» (Russian Federation). An average arithmetical variation line $(M)$ has been defined $( \pm m)$, reliability of parameters variety has been determined by Student $(t)$ criterion. The levels of serum and induced of cytokines, in vitro, have been confirmed by Pearson's statistical processing.

Results and discussion. According to preliminary results the initial levels of studied cytokines statistically insignificantly exceeded the norm in most patients with brain malignant tumors. During the treatment there are no changes in the indices as raIL-1 and IL- 6 and IL-8, with the exception of 2 cases. Lack of significant changes in serum concentrations of cytokines studied in the- se patients, is perhaps a sign of growing depletion of antitumor immunity, as a result of reactivity of the immune system. In the patients who have lung cancer, the serum level of raIL-1 was higher in $52 \%$ of cases $(1732 \pm$ \pm 15 ), and there was a tendency of decrease of this indicator. As to IL-8 and IL-6 indices of those patients, the concentration of former in the blood serum that was initially high (1.5 times) remained on the same level by the end of the research, whereas the average level of IL6 was slightly higher during the I investigation in $70 \%$ of cases and decreased by the end of research, almost getting to the normal level. Taking into consideration published data, the production of IL-8 increases when a patient has benign tumor, perhaps, the change of serum levels in its dynamics may be a criterion of immunodiagnostics of a patient having lung cancer.

RaIL serum was raised in 70 patients with polytrauma, and by the end of treatment tended to reduce this figure. As for the indicators 6 and 8 in the same patients, the concentration of the first serum was originally raised in more than half of them, as in several studies reduced by the end of the research, while the average level of IL- 8 was initially raised in $80 \%$ of cases $(56.2 \pm$ \pm 4.9 ), and also reduced by the end of the study, almost reaching the normal range. In the literature there is an evidence that low concentrations of raIL-1 are associated with a worse prognosis, perhaps, explains places without restriction or activity of endogenous IL-1, inducing the state similar to septic shock. Increasing concentrations of IL-6 and IL-8, is perhaps a marker of tissue destruction, an increase in the serum concentration of raIL-1 antagonist may be an additional sign of developing inflammation.

Study on serum concentration VEGF in the blood of 58 patients having cancer of bladder showed considerable dependence between increased serum level of the marker and level of tumor malignance as well as how the process is spread. So, the concentration of VEGF in the patients with higher level of malignance (G3) was $285.9 \pm 27.2$, slightly decreasing by the end of the study $(217.2 \pm 22.7)$, whereas in those having low level of tumor malignance there was a reduce in its consistency by the end of the research (respectively $247.5 \pm 12.3$ and $107.5 \pm 14.3$ ).

Serum level of VEGF was considered among 24 patients with polytrauma - during I study the concentra- 
tion of VEGF was $183.8 \pm 15.2$, statistically rising by the end of the study $(296.2 \pm 26.7)$, and the majority of patients with favorable process of disease had a statistically remarkable reduction inserum concentration VEGF $-147.5 \pm 12.3$, whereas the patients with poor prognosis during the first research had serum level of $102.23 \pm 7.2$, having almost the same level throughout the whole period of study (respectively, 111.2 \pm 9.4 and $85.7 \pm 11.4$ ).

We carried out a correlational analysis of serum levels and induced in vitro cytokines to identify similarities and differences, especially violations of their synthesis, in order to find the ways how to influence their regulation under different pathological conditions, and to monitor the dynamics of their changes. According to the results, in patients with malignant tumors a positive correlation (statistically significant) in serum levels of studied cytokines was noted between $\gamma$-IFN and $\alpha$-IFN, between $\gamma$-IFN and $\alpha$-TNF, and between $\alpha$-TNF and IL-4. In patients with polytrauma and sepsis statistically significant positive correlation was in concentrations of serum between raIL- 1 and IL-8, between $\gamma$-IFN and $\alpha$-TNF, and between IL- 6 and IL- 8 .

For in vitro cytokine production in the dynamics of treatment in patients with malignant tumors there was revealed positive correlation between $\gamma$-IFN spontaneous and induced, and IL-4 induced and spontaneous.

In patients with polytrauma and sepsis, positive correlation between in vitro cytokine production was noted for $\gamma$-IFN spontaneous and induced, and $\alpha$-TNF induced and spontaneous. IL-4 did not correlate with any of the other cytokines and with each other (spontaneous and induced levels).

The results obtained will encourage the selection of the most informative biomarkers of diagnostic and prognostic significance with regard to the return of the disease, metastasis, the possibility of purulent septic complications for a differentiated approach to immunodiagnosis and immunotherapy in various pathological conditions.

\section{3. Р. Тер-Погосян}

Параметри цитокінової регуляції як додатковий критерій імунодіагностики

Резюме

Мета роботи полагала в пошуку інформативних параметрів циитокінової системи для лабораторної діагностики при пухлинній $i$ непухлинній патологіях. Методи. Вивчено концентрації IЛ-4, 6 , 8, раІЛ-1, IФН-альфа, -гамма і VEGF у хворих з пухлинною $і$ непухлинною патологіями. Результати. Вихідні рівні досліджуваних цитокінів перевишували норму у більшості хворих із злоякісними пухлинами мозку. Ухворих на рак легені рівень раІЛ-1 у сироватиі крові спочатку був підвищеним і наприкіниі лікування спостерігалася тенденція до зниження иього показника. Концентрація ІЛ-8 у сироватиі крові, збільшена на початку, у $82 \%$ пацієнтів залишалася на попередньому рівні наприкіниі дослідження, тоді як середній рівень ІЛ-6 за незначного підвищення спочатку під кінець дослідження знижувався, майже сягаючи норми. Сироватковий рівень раІЛ-1 виявився збільшеним у $70 \%$ хворих з політравмою $i$ знижувався під кінець лікування. Показники ІЛ-6 та ІЛ-8 у тих же хворих, підвищені на початку, також незначно зменшувалися наприкіниі дослідження. Концентрачія VEGF у хворих із високим ступенем злоякісності (G3) трохи знижувалася під кінеиь дослідження, а за низького ступеня злоякісності відмічено статистично вірогідне ї̈ зменшення. У хворих з політравмою рівень VEGF підвищувався наприкінщі дослідження, при иьому у більшості обстежених із сприятливим перебігом захворювання спостерігали статистично значуще його падіння. Висновки. Отримані результати сприятимуть відбору нійінформативніших біомаркерів з дiагностичною і прогностичною значущісстю.

Ключові слова: иитокіни, імунодіагностика, пухлини, політравма,сепсис.

\section{3. Р. Тер-Погосян}

Параметры цитокиновой регуляции как дополнительный критерий иммунодиагностики

Резюме

Цель работы состояла в поиске наиболее информативных параметров цитокиновой системы для лабораторной диагностики при опухолевой и неопухолевой патологиях. Методы. Изучень концентрации ИЛ-4, 6, 8, раИЛ-1, ИФН-альфа, -гамма и VЕGF y больных с опухолевой и неопухолевой патологиями. Результаты. Исходные уровни изучаемых цитокинов превышали норму у большинства больных со злокачественными опухолями мозга. У больных раком легкого уровень раИЛ-1 в сыворотке крови вначале был повышен и к кониу лечения наблюдалась тенденщия к снижению этого показателя. Концентрация ИЛ-8 в сыворотке крови, изначально увеличенная, у $82 \%$ паџиентов оставалась на прежнем уровне к кониу исследования, тогда как средний уровень ИЛ-6 при незначительном повымении вначале к кониу исследования снижался, почти достигая пределов нормы. Сывороточный уровень раИЛ-1 оказался возросшим у $70 \%$ больных с политравмой и снижался к кониу лечения. Показатели ИЛ-6 и ИЛ-8 у тех же больных , изначально повышенные, также несколько уменьшались $\kappa$ кониу исследования. Кониентрация VEGF у больных с высокой степенью злокачественности (G3) немного понижалась к кониу исследования, при низкой степени злокачественности отмечено статистически достоверное ее уменьшение.У больных с политравмой уровень VEGF повышался к кониу исследования, при этом у большинства обследованных с благоприятным течением заболевания наблюдалось статистически значимое его падение. Выводы. Полученные результаты будут способствовать отбору наиболее информативных биомаркеров, имеющих диагностическую и прогностическую значимость.

Ключевые слова: ичитокины, иммунодиагностика, опухоли, политравма,сепсис. 


\section{REFERENCES}

1. Drannik G. N. Clinical immunology and allergology.-Moscow: Med. Inform. Agency, 2003.-604 p.

2. Agadjanov V. V. Polytrauma. Septic complication.-Novosibirsk: Nauka, 2005-385 p.

3. Afanaseva A. N., Odintsova I. N., Udut V. V. Syndromes of endogeneous intoxication and of system inflammation response. Generality and differences // Anesthesiology and Reanimation.2007.-N 4.-P. 67-70.

4. Berejnaya N. M. Clinical immunological investigation-state of question // Immunology.-2006.-N 1.-P. 18-23.

5. Okuneva O. S., Taranushenko T. E., Calmina A. B., Debianova I. M., Morgun A. V. Investigation of cell markers of neuronal and glial natures at perinatal lesions of central nervous system // CNS.-2009.-10, N 1.-P. 50.

6. Blay J.-Y. Multiple roles of endogenous cytokines in human cancer // Biologie des tumeurs.-2001.-250.

7. Fuhrmann-Benzakein E., Ma M. N., Rubbia-Brandt L., Mentha G., Ruefenacht D., Sappino A. P., Pepper M. S. Elevated levels of angiogenic cytokines in the plasma of cancer patients // Int. J. Cancer.-2000.-85, N 1.-P. 40-45.

8. Abbas A. K., Lichtman A. H. Les bases d'immunologie fondamentale et clinique.-Amsterdam: Elsevier, 2009.-299 p.

9. Beloborodova N. V., Bachinskaia E. N. Immunological aspects of postoperative sepsis // Anesteziol. Reanimatol.-2000.-N 1.P. 59-66.
10. Blagoveshenskiy S. V., Vinnitskiy L. I., Cherepakhina N. E. Intracranial pyoinflammatory process: characteristics of immunology and pathogenic and clinical assessment thereof // Allergology and Immunology.-2005.-N 6.-P. 145.

11. Buniatyan K. A., Inviyaeva Y. U., Vinnitskiy L. I. Problems of disturbed immune regulation in surgical clinic (diagnosis and treatment) // Allergology and Immunology.-2005.-N 6.-P. 143.

12. Dwyer M. J., Ryan T. The «cytoscore» predicts survival in severe sepsis // 21-th ESICM Annual Congress.-Lisbon, 2008.P. 196.

13. Seekamp A., Van Griensven M., Lehmann U., Molituris U., Pohlemann T. Serum IL-6, IL-8 and IL-10 levels in multiple trauma compared tu traumatic brain injury and combined trauma // Eur. J. Trauma.-2002.-28, N 3.-P. 183-189.

14. Gusev Y. U., Osipenko A. I. Immunology of system inflammation // Russ. J. Immunol.-2001.-6, N 1.-P. 4-8.

15. Kozlov $V$. K. Immunopathogenesis and cytokinesis of surgical sepsis.-Saint-Petersburg: Dialect, 2002.-48 p.

UDC 615.277.3:615.36/3700016 Received 20.06.11 